\begin{tabular}{|l|l|l||}
\hline \multicolumn{2}{|c|}{ PublisherInfo } \\
\hline \hline PublisherName & $:$ & BioMed Central \\
\hline \hline PublisherLocation & $:$ & London \\
\hline \hline PublisherImprintName & $:$ & BioMed Central \\
\hline \hline
\end{tabular}

\title{
Calibrating chips
}

\begin{tabular}{|l|c|l||}
\hline \multicolumn{2}{|c|}{ ArticleInfo } \\
\hline \hline ArticleID & $:$ & 4497 \\
\hline \hline ArticleDOI & $:$ & $10.1186 /$ gb-spotlight-20020606-01 \\
\hline \hline ArticleCitationID & $:$ & spotlight-20020606-01 \\
\hline \hline ArticleSequenceNumber & $:$ & 163 \\
\hline \hline ArticleCategory & $:$ & Research news \\
\hline ArticleFirstPage & $:$ & 1 \\
\hline \hline ArticleLastPage & $:$ & 2 \\
\hline \hline & & RegistrationDate : 2002-6-6 \\
\hline ArticleHistory & $:$ & OnlineDate \\
\hline \hline ArticleCopyright & $:$ & BioMed Central Ltd2002-6-6 \\
\hline \hline ArticleGrants & $:$ & \\
\hline \hline ArticleContext & $:$ & 130593311 \\
\hline \hline
\end{tabular}




\section{Jonathan B Weitzman}

Email: jonathanweitzman@hotmail.com

The use of relative expression ratios from microarray hybridization experiments hinders comparison of different experimental conditions and does not indicate absolute expression levels. In the May 28 Proceedings of the National Academy of Sciences, Aiméé Dudley and colleagues at Harvard Medical School describe an approach based on computational and experimental methods to improve the accuracy and utility of microarray data (Proc Natl Acad Sci USA 2002, 99:7554-7559). Their approach incorporates comparison with a calibrated oligonucleotide reference sample containing sequences complementary to every microarray spot. They also used spot intensity data from multiple scans at different detection sensitivities and applied linear regression algorithms to generate a common linear scale. Dudley et al. applied their technique to yeast microarray experiments to demonstrate its effectiveness. This method should allow for improved data comparability and estimation of true transcript abundance.

\section{References}

\section{Proceedings of the National Academy of Sciences, [http://www.pnas.org]}

2. Harvard Medical School, [http://www.med.harvard.edu]

3. Measuring absolute expression with microarrays using a calibrated reference sample and an extended signal intensity range: supplementary material, [http://arep.med.harvard.edu/masliner/supplement.htm] 